\title{
Feminist Research Methodologies: An Analysis Of Graduate Level Dissertations At CEWS
}

\author{
Dua-e-Rehma \\ \& \\ Seema Manzoor \\ Women's Studies \\ University of Karachi \\ Nasreen Aslam Shah \\ Social Work \& Women's Studies \\ University of Karachi
}

\begin{abstract}
The study is about learning of feminist research and its application at academic level. The aim of this study is to analyze attitudes of feminist students towards feminist research in order to conduct research in feminist perspective and select topics, methodologies, sample as well as data collection tools and analysis. A sample of 50 M.A. dissertations of different topics of the year 2013-2014 has been selected from the Centre of Excellence for Women's Studies University of Karachi. Selected topics of sample thesis are based on women's issues and general social issues. The analytical approach is used with quantitative research methods. Purposive and convenience sampling methods of non-probability sampling are applied. The study observed that students attempted to research and analyze the selected topics from a feminist perspective. Results show that majority of the students apply mix methodology in their researches. They usually select common issues of women for research. There is a need to raise more themes about women and gender issues to bring social change.
\end{abstract}

Keywords: Feminist Research, Qualitative and Quantitative Research, Methodology.

$$
\begin{aligned}
& \text { تلخيص }
\end{aligned}
$$

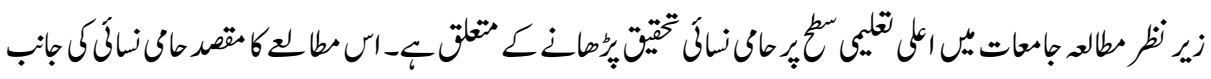

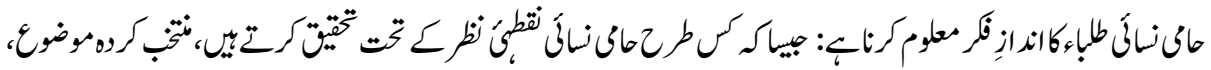

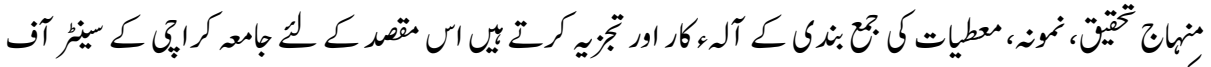

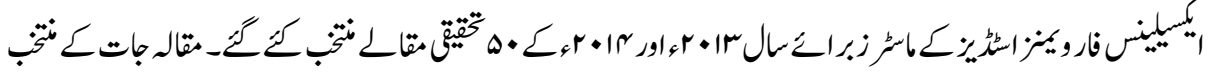

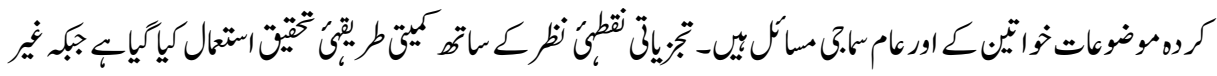

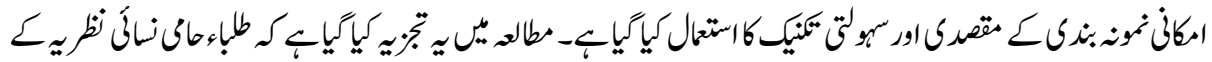

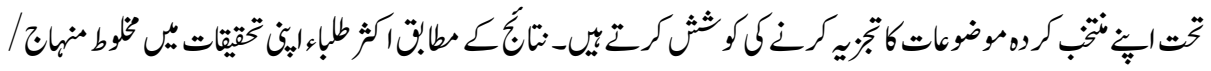




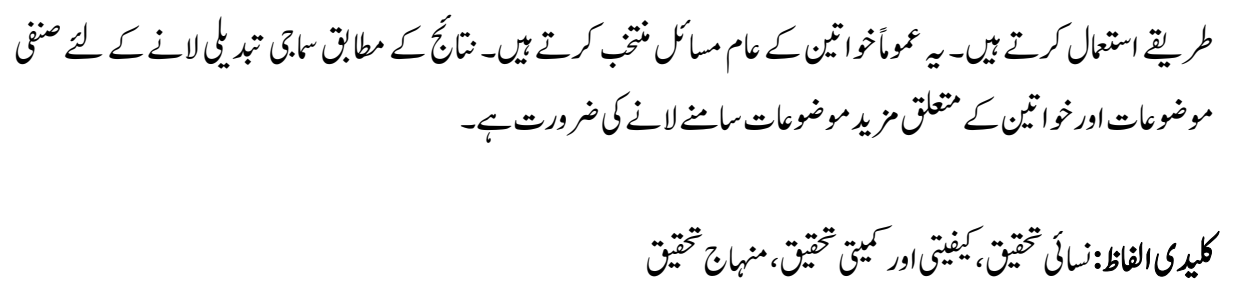

\section{Introduction}

Human beings have multitude attributes and uniqueness. Some attributes are genetically developed; some create through experiences and intelligence. Curiosity is one of the attributes and parts of human nature. Being curious about knowing is like being hungry for food and motivates for food. Basically curiosity, interest, and discovery are the thirst of getting knowledge. This feature leads humans towards pondering, learn and discover. It helps to understand phenomena of life and universe which interlinks to each other. This obligates them to do research for higher visions and greater purposes.

Research is a dynamic element of human life to seek knowledge, make innovations and inventions in the world, and uncover the realities, its influences and interconnected matters between humans and society. By knowledge humans develop theories, ideologies, rules and regulations and new techniques. Research is a systematic way to create knowledge, establish facts and seek the answers to such questions which need to be explore (Grinnell \& Grinnell, Unrau, 2005).

The question arises here how to conduct research? There are several research methods, which are crucial components of natural and social sciences. Social sciences are not as easy as generally people think, but complex than natural sciences. Social sciences study the social phenomena and emphasize on challenges faced within society. Social sciences develop a relationship among social issues, social theory and research (May, 2001). It explores the answers to research questions through research techniques, by making a research design on the basis of methods use for data collection and determine that how it would be analyzed.

Feminist research is a disciplinary research of social sciences. Feminist researchers aim to do feminist research for social transformation and bring social change for women and other oppressed groups. They have empathy and subjectively understand the participants. It is a learning process for feminist researchers and participants as well. Feminist researchers aim to change an individual's life. Feminist research methodology and conventional research are quite debatable, but still, there is a need to find a definite answer (Harding, 1987). Feminist research scholars have also argued about ignorance and exclusion of women due to positivistic quantitative methods (Oakley, 1997). They include 
women into knowledge which is gathered from the male perspective. Dr. Jane Wambui mentions Bohan (1992) that feminists have criticized the conventional research methods such as experiments and survey, which make women invisible in society. Feminists have consistently emphasized the importance of women in social context. Thus, feminist methods are contextual that is, avoid focusing on the individuals in isolation, who bring to a halt from interactions and relationships with other people (Wambui, 2013).

Generally, research methods are dichotomized in quantitative and qualitative methods. These techniques are used for gathering research data (Harding, 1987). Research methodology is being criticized regarding gender issues. The quantitative methods are considered as scientific, statistical, and objective and patriarchal in nature in the view point of feminists. Unlike quantitative research, qualitative research methods are considered as unscientific, subjective and empathetic in nature (Oakley, 1997; 1998). Feminist research scholars argue about male supremacy in social sciences. For this reason they include women in the production of knowledge in which women were excluded because quantitative research is male centered.

Feminist scholars have a common consensus that this research methodology is not just about women but for women and with women. Feminists use some of the existing methods while formulating the new methods as well in feminist research (Reinharz, 1992). It is accepted that feminist research methods have extended the issues from women to gender, which have been neglected on the basis of class and ethnicity. Hammersley (1992) argued that feminist research is not only about women but it is gender based. Because women and men are related to each other, so it is not possible to deal with them as single entity. The study of external world should also be done in relation to women's experiences which they go through in everyday life.

There is a variety of programs and departments established for women's studies, women and gender studies discipline which started since the first wave of feminism. It has grown in higher education throughout the world, as an agenda of a decade for women. These programs introduce the certificate and degree courses at a variety of universities, colleges, and institutes. The gradual increase of studies and scholarships on women and gender issues introduced the new academic discipline of feminist research. Students pursue this degree and certificate as a major and minor subject while creating opportunities for students in the development sector. The program may differ from country to country, from college to college, and university to university. All the programs have featured courses in which feminist research is the core subject of every program (Raynolds, Shagle \& Venkataraman, 2007).

Research methods are essential part of social sciences academics. The research courses are taught globally at Masters and M.Phil/Ph.D level. The aim of research courses is to 
develop understanding, awareness and gaining knowledge, so that students may conduct researches on a thematic area of their interest by applying an appropriate research design, analyze data and then deduce the results and conclusions. This is a common practice which can be seen at universities and higher secondary institutions where students do researches to pursue the degree. Hence gender and women's studies discipline also have a prestigious field of feminist research.

In Pakistan, women's studies became the part of social sciences since 1989. This project started by Women's Development department at five universities. The aim of this project was to promote action researches and academic dissertations about women and gender issues. Discipline critically analyzes the theories and methodologies shaped from a perspective of male hegemony and develop a course to reshape the women's status and vision (Hafeez, 1995). In Pakistan, numerous researches and studies have done before and are still in progress, but very few feminist studies conducted by feminist scholars using feminist methods. Hence there is an opportunity to learn feminist research techniques, to do researches by feminist standpoint on issues of women, gender, and society. There are countless themes to conduct researches from feminist viewpoint applying feminist research methods.

\section{Review of Literature}

Researchers have different purpose of doing research mainly to fulfil their academic requirements at graduate and post graduate level for career development. Another aim is to seek for learning and teaching at colleges and universities, to delve into finding reality, solving and challenging the problems, to bring a social transformation for better life and fulfilment of curiosity. They learn research guidelines properly in courses. These students can grow to be a good researcher by encouraging themselves towards their goal (Rajasekar et al., 2013). In the University of Cambridge, during post-graduate courses, involving students into doing research is a learning process includes doing mini researches and assignments. They use different types of research methods as well as evaluation of the published studies. It makes students capable of choosing a topic for submitting a final dissertation (Taber, 2010).

At the academic level for feminist research discipline, feminist students conduct research on women's issues to include women into the knowledge where women exclude and support gender equality. This research discipline interprets women's knowledge in academics, theories, researches, methodologies, history and politics (Marshall and Young, 2006). Historically glimpse why there had been a need for feminist research and knowledge which include women because in past times the modern sciences and technology was an aspect of colonization. Such science and modern inventions were in the hands of Europeans, and scientific topics chose by researchers which excluded 
women from knowledge. Tickner (2003) expressed the analysis of Sandra Harding in working paper that culturally there are different methods and topics for realism which is non-scientific (Harding, 1998).

Feminist Scholars have taken up methodologies which are based on theme accordingly as well as appropriate. Feminists argued that quantitative methods reject the woman's identity and experiences and explicitly inconsistent with feminist goals (Mies, 1983; Oakley 1997). Reinharz (1992) highlighted that survey-based data is useful for looking at the prevalence of particular social problems. Feminist researchers prefer qualitative research method for better understanding of women and gender-based problems. Qualitative research is subjective and provides in-depth knowledge about feelings and situation while the quantitative approach is objective in the viewpoint of feminists (Maynard, 1994). Feminists also argued that quantitative research uses people as an object material to subordinate the individuals (Campbell \& Schram, 1995). Historically feminists prefer qualitative research methods and consider important and valuable, hence, using both qualitative and quantitative research is also given priority by many feminist research scholars. Quantitative methods are also used by feminist researchers, keeping in view that feminists use feminist rules while applying both methods (Letherby, 2003). Both research methods are useful and it is dependable on research questions and its objectives although must not violate the feminist rules. They should explore and encourage the feminist goals. Feminists advocate the use of mix methodologies to make the data more practical and accommodating the feminist agendas; hence for making the feminist research more realistic feminist students pursue studies on a wide range of issues about both men and women. Consequently, students learn techniques in feminist research class for conducting a research.

For practical pedagogy, feminists use same methods as by other social researchers, feminist scholars have also composed these methods for the feminist purpose. For a particular theme, particular methods apply which integrate gender, empathy and empowering women. They construct more reliable data and consciousness about challenges as they face being a feminist and carry on feminist goal (Reinharz, 1992). For social research students, student-centred teaching methods are helpful in enhancing knowledge. It has a positive impact on students learning by which students experience subjects at different perspective (Barraket, 2005). Hence they learn how to do a research, and which subject to choose and share the experiences of research at the student level. This phase is more helpful for enhancing and build up the knowledge.

Feminist pedagogues emphasize that gender-related topics should teach for raising consciousness about gender, equality, and justice. Feminist teachers can bring a change in classrooms by choosing gender-related topics. It will help students to get 
awareness about sexism, justice, and social change. It is a qualitative approach by which students learn. The qualitative approach of research methodologies is valuable among feminist research scholars (Reiko, 2014).

Feminist scholars point out that feminist research develops a relationship and confidence between researcher and respondent. This research approach analyzes race, gender, class, and undergo women's experiences. This feature of feminist research improves women's lives (Harding \& Norberg 2005; Reinharz, 1992). Hence it is a learning process for both researcher and subject in applied research. The terms of applied learning or learning by doing used by N. Alexander Aguado (2009) mentions practical learning is very useful for the students. He mentions the approach of empirical research methods is helpful to educate students about doing research in social sciences for public assessments. It is a strategy of learning process for students and teachers. In this way, teachers and research scholars share their experiences about doing research, when they did in particular area. It incorporates students into active research directly through which learning process and research put together.

Similar views developed by Manicom (1992) that in universities feminist teachers' practice to enquire social world critically, having a remarkable intensity and gazing towards issues. Their practices must reflect in the classrooms. The feminist class necessarily a place where women's experiences must be shared, and critically analyze the gender-based issues. In the feminist pedagogy practices teacher-students analyze the same nature of experiences. This relationship of teacher-student and learning process develop new ideas of research, methodologies and social change.

A similar practice of learning feminist research is applied to some extent in Pakistani Universities. Women's and gender studies discipline promotes research in feminist students. It mentions its significance and reinforces the local feminist standpoint. Students take up various issues of women, gender and social concerns at Masters' level dissertation. These researches take place in small areas which show the comparative and multipurpose perspectives. Feminist research students include both men and women leading to graduate and post-graduate. Some students who enroll in Ph.D. cater academia by working on various issues. There are many challenges for doing feminist research in Pakistan, but the feminists, gender experts, and academicians have involved in applying feminist research techniques at different levels while doing research. Many studies have done for women from women, but there is still a need for theoretical perspectives must interlink with feminist research techniques and critical research methods for in-depth study (Ahmad, 2010). 
Asad and Allana (2015) also examined the research topics in Pakistan regarding feminist viewpoint. They pointed out studies conduct on women as gender work rather than men and women's experiences separately, while feminists talk about experiences of women and men as gender. The process of engendering will complete to integrate both men and women. Their study followed feminist standpoint in thirty-five selected pieces of research which incorporated gender concepts and deals with patriarchal values which affect women, sexual violence, women's rights, girl and boy child rearing practices and socioeconomic conditions of women (Asad \& Allana, 2015). Now the question arises how much these researchers are aware of feminist research techniques and tools, and how they utilize them for the sake of women's issues and gender. In Pakistan, there is a need for series of feminist research work because the situation women are different due to class differences at rural and urban level. They suffer hindrances which are predominantly existed on the name of religion, cultural values, and ideologies. The implication of the feminist theory in Pakistani context is inevitable due to gender inequality and discrimination in all the spheres of life. Existing cultural practices restrict the feminist researchers for conducting research on women issues from feminist view. The work of Pakistani feminists confronts the patriarchal power and several social challenges (Jabeen \& Jabeen, 2013).

Marwat (2016) pointed out that students' mindset towards feminist research that, feminist students learn about women empowerment and gender integration from their curricula. They have a patriarchal and misogynistic approach regarding women and gender equality deep inside due to the social structure in which they grow. The problem is feminism is viewed as secular thought by people who have a strict ideology of Islamization and misogynistic notions.

It is clearly observed since several decades feminist research scholars have been more thoughtful regarding research process in feminist standpoint. They have formulated new methods of research despite adapting existing methods of creating knowledge which explores experiences and influences on women and gender. Hence they introduced a discipline and undertaking the themes of women and gender experiences into action research (Krook, 2007). For this reason, feminist students must take these methods into consideration to build knowledge. The feminist research is feminist in nature in the sense of its ideas, beliefs, aims and relationship which provide a research framework. Feminist research methodology differs due to the facts that it uncovers and challenges the power disparity of both participants as researcher and subject. It has the perspective of 'personal is political', taking initiatives for social change and it has a unique feature of the learning process (Landman, 2006). Feminist research methods include women's perspective in traditional patriarchal understandings, which neglect and oppress women and its capabilities. 


\section{Methodology}

This brief study focuses on the significance and worth of feminist research and methodology applied at Masters level thesis from 2013 and 2014. The study also focuses on the understanding of students about their application of methodology according to the research problem. Quantitative methods are used in this study, and analytical approach is also applied to examine the research methods which are apt and valuable according to a research topic. The sample of 50 Masters' level dissertations of different topics have selected, which students prepared for the partial fulfillment of Master's degree. Focused research topics of students have considered more valuable and researchable thus included such as Legal issues, Women based issues, Social issues, Cultural issues and Gender-based issues. It is analyzed that research problems are particularly women oriented and based on commonly prevailed social issues meanwhile the students have conducted researches mainly on feminist issues. Purposive and convenience sampling techniques of non-probability sampling methods used to select the sample of M.A dissertations from Centre of Excellence for Women's studies, University of Karachi.

Table: 1

Distribution according to the topics

\begin{tabular}{|l|c|c|}
\hline Topics & Frequency & Percentage \\
\hline Legal issues & 1 & $2 \%$ \\
\hline Women based issues & 43 & $86 \%$ \\
\hline Social issues & 3 & $6 \%$ \\
\hline Cultural issues & 1 & $2 \%$ \\
\hline Gender based issues & 2 & $4 \%$ \\
\hline Total & $\mathbf{5 0}$ & $\mathbf{1 0 0 \%}$ \\
\hline
\end{tabular}

Data shows the research topics of students selected for conducting research, $86 \%$ topics are related to women's issues, $6 \%$ topics are related to social issues meanwhile, $4 \%$ topics are gender-based topics.

Table: 2

Distribution according to the research methodology

\begin{tabular}{|l|c|c|}
\hline Research methodology & Frequency & Percentage \\
\hline Quantitative/Qualitative & 40 & $80 \%$ \\
\hline Qualitative/Case studies & 1 & $2 \%$ \\
\hline Content Analysis & 9 & $18 \%$ \\
\hline Total & $\mathbf{5 0}$ & $\mathbf{1 0 0 \%}$ \\
\hline
\end{tabular}


Data shows the research methodology applied in these dissertations in which $80 \%$ students have used qualitative and quantitative methods, $18 \%$ students have used content analysis and $2 \%$ have used only qualitative methods and case studies for conducting researches. This data shows the understanding of students about methodology.

Table: 3

Distribution according to sampling technique

\begin{tabular}{|l|c|c|}
\hline Sampling Technique & Frequency & Percentage \\
\hline Purposive & 9 & $18 \%$ \\
\hline Convenience & 13 & $26 \%$ \\
\hline Mix sampling method & 25 & $50 \%$ \\
\hline Random & 2 & $4 \%$ \\
\hline Snow ball & 1 & $2 \%$ \\
\hline Total & $\mathbf{5 0}$ & $\mathbf{1 0 0} \%$ \\
\hline
\end{tabular}

Data shows sampling techniques have used by students in their dissertations, $50 \%$ students have used mix sampling techniques, $26 \%$ students have used convenience sampling while $18 \%$ students have used the purposive technique of non-probability sampling.

Table: 4

Distribution according to data collection tools

\begin{tabular}{|l|c|c|}
\hline Data Collection Tools & Frequency & Percentage \\
\hline Questionnaire & 17 & $34 \%$ \\
\hline Interview schedule & 32 & $64 \%$ \\
\hline Content Analysis & 1 & $2 \%$ \\
\hline Total & $\mathbf{5 0}$ & $\mathbf{1 0 0} \%$ \\
\hline
\end{tabular}

Data shows tools for data collection which is used by research students, $64 \%$ students have used interview schedule, and 34\% students have used questionnaire as a tool and 2\% students have used content analysis chart for their data collection of research.

Table: 5

Distribution according to analysis of data

\begin{tabular}{|l|c|c|}
\hline Analysis of Data & Frequency & Percentage \\
\hline Simple Frequency distribution & 40 & $80 \%$ \\
\hline Content Analysis & 10 & $20 \%$ \\
\hline Total & $\mathbf{5 0}$ & $\mathbf{1 0 0 \%}$ \\
\hline
\end{tabular}


Data shows Analysis of data by simple statistical methods has used by students, $82 \%$ students have used simple frequency distribution method by tabulation while 18\% students have analyzed data by content analysis methods which help in deducted the results of research.

\section{Discussion}

Feminist Research has become worthy since feminist scholars identified the male hegemony in social sciences research. Feminist scholars also criticized the methods of research and research problems which excluded women. According to Reinharz (1992), feminist methodology helps to improve women's lives and social structure. Feminist research methodologies are learning more at the academic level as feminist research course in Women's studies and gender studies programs. Students pursue this degree as career, to learn about changes in society, women's lives experiences and her role throughout the history. This discipline is started in Pakistan at governmental level in five universities to promote academic curricula about women and initiate research work about and for women and gender in association with society. For this purpose, the Centre of Excellence for Women's Studies is playing its significant role. The Centre is offering B.S (honors)/Masters and M.Phil./Ph.D. programs. Their curriculum has Feminist Research course which teaches in two semesters and students have to prepare a thesis for executing their degree. Students learn necessarily, the techniques of doing research in order to be acquainted with feminist research. Through this course, students learn how to do a research, feminist research, and difference between two Feminist and social research methodologies. Throughout the two semesters, they involve in class discussions and prepare short assignments about research techniques and topic selection. In the final year, students first choose a research topic of their choice which bases on different issues regarding women, gender, and society. After selection of a research topic, the methodology is decided in relation to the topic.

According to the research findings Table No.1, 86\% students have chosen women's based issues, while $6 \%$ students researched on the topic of social issues and $4 \%$ students selected gender-based topics. This points out that students examined the women based issues as feminist, other percentages about gender and social problems are also related to women to some extent, while students tried to analyze the research problems in the feminist perspective. The studies on women based issues are on divorce marriage, gender discrimination, socioeconomic issues, psychological and health problems. By examination of topics about women based issues, it is found that students select commonly prevailed themes about women's problems. For raising awareness, and experience the women's issue, students may expand the themes from most common to taboo, invisible to visible issues. Feminist research methodology is about social change, social justice and empowerment of women (Fonow\& Cook, 2005; Krook, 
2007). Feminism in Pakistan is introduced by women, for women and headed by women as well. It considers as the only realm of women while men condemn feminism as a distortion of a pre-existing social structure. However, the status of women still needs to be enhanced. The problems of Pakistani women should expose and sort out which are the result of a patriarchal notion.

The procedure of research used by students, shows in Table No.2, $80 \%$ students applied both qualitative and quantitative research, $18 \%$ students applied the method of content analysis while only $1 \%$ students used the qualitative methods. The high percentage shows the trend of multiple or mix methodology application by students in which they usually adopted survey, face to face interviews and case studies. Students also did their academic dissertations on different contents related to the advertisements, religious scriptures, and media. The lowest trend shows a limited perspective of students towards qualitative methodology whereas more prefer by feminist scholars. Feminists argued on quantitative research methods which cause invisibility of women. Nowadays feminists consider both research methods are useful and important in feminist research and this choice should be dependent on the objectives and explorations. However feminist researchers use the quantitative approach in a way that does not disrupt the feminist principles and encourage the feminist goals which are revealed by Miner-Rubino \& Jayaratne (2007) as well. Similarly, the methodology should be compatible with the topic and content of research. The connection between topic and methodology is very noteworthy, it gives better results.

Nevertheless, there is a range of methods which can use as feminist research methods. It is evident that the practice of qualitative research is more desirable and ideal for feminist researchers. Hence feminist students must be motivated towards qualitative methodologies through which they can make evidence about women's issues, women's experiences and socio-cultural and economic issues about women's lives and experiences at the academic level. This activity helps them to become a true feminist in future. Some feminists have a clear perspective that multiple methods should employ to get a clear picture of the following; what is a problem? What is a reality? How may they seem? How people percept about and reasons behind the scenes?

In research methodology, the sampling techniques are the most important element. According to the results of Table No.3, 50\% students used mixed sampling methods of the non-probability and probability sampling method. $26 \%$ students collected data by applying convenience sampling technique of non-probability sampling, whereas $18 \%$ students applied the purposive type of non-probability sampling, while 4\% students applied the random method of sampling and only $1 \%$ students used snowball technique of non-probability sampling method. At the academic level, the sample is not so extensive hence non-probability sampling methods use and more preferable in dissertations. For doing a feminist research, a small sample is better than a large sample for deeper 
understanding and better results, therefore non-probability sampling is feasible. According to the findings of Table No.4 about data collection tools 64\% students collected data through interview schedule, $34 \%$ collected data by questionnaire while $2 \%$ used content analysis chart as they conducted a research based on content analysis. This shows interview schedule use by feminist students in feminist research is very crucial to collect data from women. Through this data collection tool, qualitative data gather by doing interview and observations, which makes data more trustworthy and meaningful. A questionnaire is generally used for quantitative research but open-ended questions makes it qualitative. This study is also analyzed that students use questionnaire according to their own understanding rather than according to a research topic. According to Table No.5 for collected data $82 \%$ students used simple frequency distribution, while $20 \%$ students analyzed data by content analysis method.

As per data of the study, clearly shows that students use mix methodology of the qualitative and quantitative method in their dissertations. Numerous experiences, knowledge, and contribution of women have not yet been noticing and analyzing within social sciences. This can only done by employing feminist research methodologies. Traditional Social sciences methods in which data collect and analyze does not offer knowledge which mentions the exact situation of women with the feminist perspective. Students of feminist discipline can collect data about women and gender by selfinvolvement through their learning and use of feminist research methods in the proper way practically. Feminist Teachers- students share their experiences and involve in action learning can learn and explore more. Self experiences of both will uncover more topics for research problems which raise and formulate the new knowledge.

\section{Conclusions}

This study examined the approach of feminist students towards feminist research and methodologies. It is found that primary goal of feminists is to produce knowledge about women, for women, and by women. The aim of doing feminist research is to see situations, problems, and experiences from the eyes of women, men and both. There is a link between learning process and practical work. Feminist teachers-students share experiences, ideas, and prior knowledge. Studying the Centre's dissertations mention that feminist students do research mostly on women based issues which are the main feature of feminist research, but there is a need to cover the unique topics about women, men, gender and their relation to social structure as well. Every theme and topic of study have its intensity of problem which seems regular in nature that needs to explore. The study is concluded that majority of students use mix methodology and have less understanding of qualitative research as feminist perspective. Students should have a clear mind about appropriate methodology which is according to a research topic. They can learn from activity learning and experiences of fields. Feminist research is not just 
for incorporate women in knowledge and shows them as a patriarchal victim, but take into consideration women's own perspectives and experiences as research foundation and originate new knowledge. There is a need of building up students towards exploring topics with new aspects and knowledge of self-experiences. Thus, they can bring a change in individuals' life. This change can be slightly positive but helping in redesigning social structure and gender perceptions positively.

\section{References}

Ahmad, Sadaf (2010). Pakistani Women: Multiple Locations and Competing Narratives, Oxford: Oxford University Press.

Aguado, N. Alexander (2009). Teaching Research Methods: Learning By Doing, In Journal of Public Affairs Education, vol.15:2, pp.251-260.

Asad, Dr. Nargis, Allana \& Dr. Anita Anis (February 2015). Gender Research in Pakistan: A Scoping Review In European Scientific Journal, Special Edition, vol.1, pp.221224.

Barraket, J. (2005). Teaching Research Method Using a Student-Centred Approach? Critical Reflections on Practice In Journal Of University Teaching \& Learning Practice, vol.2:2, pp.64-74.

Fonow, M., M. \& Cook, J., A. (1991). Back To The Future: A Look At The Second Wave Of Feminist Epistemology And Methodology. In F. Mary, \& C. Judith, (Eds.), Beyond Methodology: Feminist Scholarship as Lived Research, Bloomington: Indiana University Press, pp.1-15.

Fonow, M. \& Cook, J. (2005). Feminist Methodology: New Applications in the Academy and Public Policy, Signs: Journal of Women in Culture and Society, vol.30:4, pp.2211-2236.

Grinnell, Richard M. \& Unrau, Yvonne. A. (2005). Social Work Research and Evaluation: Quantitative and Qualitative Approaches. Oxford: Oxford University Press.

Hafeez, Sabeeha (1995). Towards Developing a Women's Studies Perspective in Pakistan: Some parameters, In Pakistan Journal of Women's Studies, vol.2:2, pp.75-97.

Hammersley, Martyn (1992). On Feminist Methodology In Sociology, vol.26:2, pp.187-206. 
Harding, Sandra. (1986). The Science Question In Feminism. Ithaca: Cornell University Press.

Harding, S. (1987). Introduction: Is There A Feminist Method? In S. Harding (Ed.), Feminism and Methodology, Bloomington: Indiana University Press, pp.1-14.

Harding, Sandra (1998). Is Science Multicultural? Postcolonialism, Feminisms, and Epistemologies, Bloomington: Indiana University Press.

Harding, Sandra \& Norberg, Kathryn (2005). New Feminist Approaches to Social Science Methodologies: An Introduction. Signs, vol.30:4, pp.2009-2015.

Hussain, Basharat \& Asad, Amir Zada (2012). A Critique on Feminist Research Methodology In Journal of Politics and Law, vol.5:4, pp.202-207.

Jabeen Dr. Farhat \& Jabeen Musarat (February, 2013). Feminism and Society: Solidarity amongst Pakistani Women Still a Distant Dream In Journal of Arts and Humanities, vol.2:1, pp.163-167.

Krook, Mona Lena (2007). Are There Feminist Research Methods?, Paper Presented At The Second Conference Of The Association Of Feminist Epistemologies, Methodologies, Metaphysics, And Science Studies, Women And Gender Studies Program, Arizona State University, Tempe, AZ, February 8-10, United States of America http://mlkrook.Org/Pdf/Krook\%20FEMMSS2\%202007.Pdf

Landman, M. (2006). Getting Quality in Qualitative Research: A Short Introduction To Feminist Methodology and Methods In The Proceeding of The Nutrition Society, vol.65:4, pp.429-433.

Manicom, Ann (1992). Feminist Pedagogy: Transformations, Standpoints and Politics, Canadian Journal of Education, vol.17:3, pp.365-389.

Marshall, Catherine \& Young Michelle D. (2006). Gender and Methodology In Skelton, C., Francis, B., \& Smulyan, L., (Eds.) The SAGE Handbook Of Gender And Education, Thousand Oaks: Sage Publications, pp.69-78.

Marwat, Inamullah (April 29th, 2016). Pakistan Needs Inclusive Feminism, Daily Times. Lahore Pakistan. 
Maynard, M. (1994). Methods, Practice and Epistemology: The Debate about Feminism and Research In Maynard, M., \& Purvis, J. (Eds.), Researching Women's Lives from a Feminist Perspective. London: Taylor and Francis, pp.10-26.

May, Tim (2001). Social Research: Issues, Methods and Process. Philadelphia: Open University Press.

Miner-Rubino, K. \& Jayaratne, T. E. (2007). Feminist Survey Research in Sharlene Hesse-Biber\& Patricia Leavy (Eds), Feminist Research Practice: A Primer, Sage Publications Inc.

Oakley, Ann (10th April, 1997). The Gendering Of Methodology: An Experiment in Knowing, Seminar to Swedish Collegiums for Advanced Study in the Social Sciences, Uppsala, Sweden.

Oakley, Ann (1998). Science, Gender and Women's Liberation: An Argument against Postmodernism In Women's Studies International Forum, vol.21:2, pp. 133-146.

Rajasekar, S., Thanjavur Poondi, \& Chinnathambi, V. (January, 2006). Research Methodology, Tamilnadu, India, pp.1-53. https://www.Scribd.Com/Doc/ 133967941/S-Rajasekar-Research-Methodology

Reinharz, Shulamit (1992). Feminist Methods in Social Research. New York: Oxford University Press.

Reynolds, Michael, Shagle, Shobha \& Venkataraman Lekha (December, 26, 2007). A National Census Of Women's And Gender Studies Programs In U.S. Institutions Of Higher Education, University Of Chicago: National Opinion Research Center (NORC).

Taber, Keith S. (2010). Preparing Teachers for a Research-Based Profession in ValencIc, Z. M., Vogrinc, J., \& Marentic-PozArnik, B. (Eds.), Facilitating Effective Student Learning through Teacher Research and Innovation. Ljubljana: Faculty of Education, pp.19-48.

Tickner, J. Ann (2014). What Is Your Research Program? Some Feminist Answers To IR's Methodological Questions In A Feminist Voyage Through International Relations Oxford; New York: Oxford University Press, pp.92-116. 
Wambui, Dr. Jane (2013). An Introduction To Feminist Research, University Of Nairobi http://Awsc.Uonbi.Ac.Ke/Sites/Default/Files/Chss/Arts/Awsc/DR.\%20JANE\%20 WAMBUI\%20AN\%20INTRODUCTION\%20TO\%20FEMINIST\%20RESEARC H.Pdf

Dua-e-Rehma is Lecturer in the Centre of Excellence for Women's Studies, University of Karachi.

Seema Manzoor is Lecturer in the Centre of Excellence for Women's Studies, University of Karachi.

Dr. Nasreen Aslam Shah is Meritorious Professor \& Chairperson in the Department of Social Work and Director, Centre of Excellence for Women's Studies, University of Karachi. 